\title{
THE IMPACT OF ETHICAL LEADERSHIP ON MEMBER'S CREATIVITY AND CAREER SUCCESS: THE MEDIATING ROLE OF LEADER-MEMBER EXCHANGE
}

\author{
DOI: 10.17261/Pressacademia.2018.944 \\ RJBM-V.5-ISS.3-2018(3)-p.202-211
}

Canan Nur Karabey ${ }^{1}$, Zisan Duygu Aliogullari²

${ }^{1}$ Ataturk University, Erzurum, Turkey. ckarabey@atauni.edu.tr, ORCID: 0000-0003-0597-3605

${ }^{2}$ Erzurum Technical University, Erzurum, Turkey.

zisan.aliogullari@erzurum.edu.tr, ORCID: 0000-0001-6602-0344

Date Received: July 17, 2018

Date Accepted: September 11, 2018

To cite this document

Karabey, C. N., Aliogullari, Z. D. (2018). The impact of ethical leadership on member's creativity and career success: the mediating role of leader-member exchange. Research Journal of Business and Management (RJBM), V.5(3), p.202-211.

Permemant link to this document: http://doi.org/10.17261/Pressacademia.2018.944

Copyright: Published by PressAcademia and limited licenced re-use rights only.

\begin{abstract}
Purpose- The aim of this study is to investigate possible direct and indirect effects (through leader-member exchange-LMX) of member's ethical leadership perception on their career success and individual creativity.

Methodology- Survey method was used to test the hypothesized effects in the proposed model. A total of 212 employees from private sector companies in a province of Turkey participated in the survey. Survey results were analysed by structural equation modelling.

Findings- The results show that ethical leadership affects LMX positively and in turn LMX has a positive and significant impact on creativity. Thus, ethical leadership was found to have only indirect effect on creativity through LMX. On the other hand, ethical leadership was found to have a positive and statistically significant direct effect on career success.

Conclusion- Working with an ethical leader brings close interaction between employee and the leader, fosters employee's loyalty to the leader and commitment to the organizational tasks beyond formal requirements. In turn, high leader-member exchange leads to an increase in employee's creativity. Moreover, if employees believe that their leader adopts ethical beliefs and performs ethically, they would be satisfied with their improvement in achieving career goals regarding promotion, salary and work success regardless of the quality of their relationship with the leader.
\end{abstract}

Keywords: Leader-member exchange, ethical leadership, creativity, career success.

JEL Codes: M54, D23

\section{INTRODUCTION}

Globalization, changing environmental conditions, increasing competition and differentiation in customer expectations made human resources one of the most important factors in organizational performance (Gürbüz, 2012). Despite the high potential of this resource, leaders and managers who have limited time are not able to establish high quality relationship with each employee. As a result the concept of leader-member exchange which refers to being close to the leader or being included in the in-group develops. The interaction level between leader and the follower is significant for the follower since the quality of this interaction is influential in him obtaining material or immaterial gains. Thus the level of interaction between leader and member has the potential to determine member's attitudes towards job and behaviour at work. Ethical leadership is an important factor which is anticipated to have an impact on the quality of the relationship between leader and member. It is observed that most of the studies on ethical leadership focus on the properties and values that should be possessed by leaders. On the contrary the studies on the relationship between ethical leadership and leader-member exchange are limited.

In recent years organizations seek for an answer to the question that what variables support and reinforce the emergence and improvement of competitive advantage in order to have sustainable competitive power. The variables soaring employees' performance, productivity and motivation have begun to be in the spotlight. Employee's creativity and career success are among those that impact their performance and motivation. Past studies confirmed the positive impact of these variables on organizational success. 
In this study, it is analysed whether ethical leaders have higher quality relationships with their members than other leaders. Also, it is examined whether ethical leaders foster higher creativity and career success among their followers directly or indirectly (through leader-member exchange). By addressing two important positive outcomes in connection with ethical leadership and leader-member exchange, this research would fill a gap in the literature and give recommendations to managers and practitioners.

\section{LITERATURE REVIEW}

\subsection{Leader-Member Exchange}

The key to success in today's fierce business world where new technologies and products copied promptly is human resource (Kanbur and Özyer, 2016, 265) and leadership is the main means to benefit from this resource. Leadership is a behavioural function by which leader attempts to affect the behaviours of others so as to achieve his/her goals (these goals could be compatible or incompatible with the goals of the organization) (Daft and Steers, 1986, 403; Can, 2005). The interaction between employee and leader has an important role in achievement of organizational goals. Leader-member exchange theory (LMX) is a leadership model based on the grounds of social interaction between leader and members. (Deluga, 1994; Harris et al., 2006). Contrary to the theories which maintain that leadership behaviour is group oriented and leader has similar interactions with all followers, LMX theory is developed on the grounds of the idea that leader has a quite different communication and relationship style with each member (Phillips and Bedeian, 1994, 990).

The theoretical roots of the development of bilateral relationship between leader and member is based on Social Interaction Theory (Blau, 1964), Role Theory (Kahn et al., 1964; Katz and Kahn, 1978) and Vertical Dyad Linkage (Dansereau, Cashman and Graen, 1973). According to LMX, employees who contribute highly to the organization and complete the tasks given by the leader successfully are taken to the in-group whereas employees who just perform in line with job definitions without attempting to exhibit extra-role behaviours are perceived in the out-group (Scandura and Graen, 1984, 429). Leader shares more resources with in-group members and provide them with better rewards. Thus the members who want to be in leader's in-group and benefit from its potential rewards establish a high quality relationship with the leader characterized by trust, respect, support and commitment whereas out-group members have low quality relationship with the leader.

LMX has been examined by Dienesch and Liden (1986) in 3 dimensions, namely contribution, loyalty and affect. Afterwards Liden and Maslyn (1998) added professional respect to this classification.

Contribution: This dimension is the perception of the amount, direction and quality of work-oriented activity each member puts forth toward the mutual goals (explicit or implicit) of the dyad (Dienesch and Liden, 1986, 624). Deluga and Perry (1994) states that contribution in leader-member exchange is a process that both leader and members obtain some mutual gains. Leaders claim that followers interacting with the leader must contribute to the work in line with organization's expectations (Jex and Britt, 2008, 322). While members exhibit extra effort and performance in the context of mutual gains, they expect their leader to guide them and provide more support and organizational resources for them (Liden and Maslyn, 1998). By this way, members who have high quality interaction with their leaders go extra miles and perform the duties expected by the leader beyond formal work requirements.

Loyalty: It is the extent to which the leader and member are loyal to one another. Loyalty was defined as the extent to which both leader and member publicly support each other's actions and character.

Affect: Dienesch and Liden defined affect as "the mutual affection members of the dyad have for each other based primarily on interpersonal attraction rather than work or professional values" $(1986,625)$. It is identified as the concept which makes each party attractive to the other and forms the interaction. Individuals have difficulty in starting interaction in work environment where there is no mutual attraction (Baş, Keskin and Mert, 2010, 1019). It is stated that impact dimension is one of the most important factors which impacts the quality and direction of LMX if the interaction between leader and member is low (Liden and Maslyn, 1998). When there is high impact in the relationship, the parties could communicate in respect and sincerity.

Professional Respect: Liden and Maslyn $(1998,50)$ defined professional respect as the perception of the degree to which each member of the dyad has built a reputation, within and/or outside the organization, of excelling at his or her line of work. Leader and members make forecasts based on their former experiences before they begin to interact in the workplace. Their respect towards the other party's former works in or out of the organization, comments about these works and the other party's reputation has a role in the development of the sincerity and the quality of the relationship between leader and member (Liden and Maslyn, 1998; Bolat, 2011).

\subsection{Ethical Leadership}

Unethical behaviour in organizations increase with the rise of complexity and performance strain in the workplace. So it is vital to eliminate unethical behaviours and establish an organizational context supportive of sustainable ethical behaviours. 
As a role model ethical leaders help followers with demonstrating ethical behaviour and they have a significant role in the deployment of ethics in the organization. Ethical leaders speak out publicly against inappropriate organizational actions and behaviours, and emphasize doing the right thing. They also convey high moral standards to employees and encourage them to voice opinions and suggestions not only on ethical matters, but also on other work-related processes.

\subsection{Creativity}

As one of the key aspects of organizational success today, creativity refers to the conceptualization, production and development of novel and beneficial ideas, processes or procedures by individuals or group of individuals in a complex social system (Shalley et al., 2000, 215; Woodman et al., 1993, 293). Leaders are expected to promote creative skills of their employees by leading them towards change and transformation. As the leader encourages individual creativity and facilitates its development in the organization, problems would be perceived and dealt with through a broader perspective and the current situation would improve significantly (Yıldırım, 2007).

\subsection{Career Success}

Although the term career is used in casual conversations quite frequently, career success is a relatively new concept. The concept of career identifies an improvement as well as performance about various occupations or roles through lifetime accompanied by some experiences and internal feelings of satisfaction (Hall and Chandler, 2005). Seibert and Kraimer (2001) described career success as the accumulation of the successes or positive outcomes regarding employee's work psychologically. Although this definition highlights psychological aspect of the concept, some researchers describing career success as the upward hierarchical movement at work highlights the objective aspect and measure it with the increase in salary and promotion (Budak and Gürbüz, 2016; Hall, 2002). In light of these explanations, career success could be evaluated through subjective or objective perspectives, but subjective career success was reported to be more important than objective evaluations in terms of career approaches (Budak and Gürbüz, 2016).

\section{DATA AND METHODOLOGY}

\subsection{Sample and Data Collection}

In this study, ethical leadership is expected to impact follower's creativity and career success both directly and indirectly. Ethical leadership is anticipated to affect leader's approach towards followers positively and it is hypothesized that it would support leader-member exchange perception of the member. This high quality interaction between member and leader would lead to member's career success and individual creativity. Past research highlighted that ethical leadership has a positive relation with organizational justice (Yıldırım, 2010; Brown et al. 2005; Neubert et al., 2009), organizational trust (Yılmaz, 2007), job satisfaction and psychological well-being (Avey, Wernsing and Palanski, 2012). On the other hand, it was found to be negatively related to mobbing (Cemaloğlu and Kılınç, 2012) and work alienation (Kesen, 2016). Regarding LMX, past research showed that high LMX has a negative impact on workplace loneliness (Cindiloğlu et al., 2017), intention to quit (Gerstner and Day, 1997) and burnout (Kaşlı and Seymen, 2010; Bolat, 2011) whereas it has a positive impact on organizational commitment (Dienesch and Liden, 1986), performance (Liden et al. 2006; Chen, Lam and Zhong, 2007), organizational citizenship behaviour (Wayne and Green, 1993) and job satisfaction (Atılmıs, 2016). Moreover, the higher the quality of the leader-member exchange, the higher member's perception of organizational justice (Erdoğan et al., 2006) and the lower member's perception of authoritative leadership (Schriesheim et al., 1992). LMX was also found to be an antecedent of creativity in many past researches (Qu et al, 2012; Peng et al., 2017; Carnevale et al., 2017; Atwater and Carmeli, 2009; Qu et al., 2017). The research also shows that high quality interaction between leader and member is influential in career success of the employee (KatI, 2016). Thus, ethical leadership and LMX could support creativity and subjective career success of the employee through fostering many positive attitudes and behaviours regarding work.

Javed et al. (2017) demonstrated that ethical leadership promotes creativity at workplace, while psychological empowerment mediates the effect of ethical leadership on creativity. In another study, Javed et al. (2018) confirmed that ethical leadership promotes creativity at workplace, while trust in leader mediates the effect of ethical leadership on creativity. Ma et al. (2013) showed that ethical leadership was positively related to employee creativity and that this relationship was mediated by knowledge sharing and self-efficacy. Mehmood (2016) found that ethical leadership is positively and significantly associated with employee creativity as well as trust; whereas, trust in leadership partially mediates the relationship between the two. Chen and Hou (2016) observed that there is a positive relationship between employee perceptions of ethical leadership and employees' voice behaviour and then voice behaviour is positively related to individual creativity. Chughtai (2016) reported that leader-member exchange and psychological empowerment fully mediated the effects of ethical leadership on employee creativity. Additionally, he found that leader-member exchange influenced creativity directly as well as indirectly through the mediating mechanism of psychological empowerment. In an experimental study, it was observed that subordinates' perceptions of their leader's behavioural integrity positively predicted their sense of psychological safety. Moreover, psychological safety positively predicted followers' intention to think creatively and to take risks (Palanski and Vogelgesang, 2011). 
The results of Gu et al.'s (2015) study showed that the relationship between moral leadership and employee creativity is mediated by not only employee identification with leader but also leader-member exchange. The research by Zahra and Waheed (2017) reveals significant positive influence of ethical leadership on innovative work behaviour that was partially mediated by meaning; self-efficacy; self-determination; and, self-impact.

In accordance with the findings of past studies presented above, the research model including hypothesized relationships is given in Figure 1:

Figure 1: Research Model

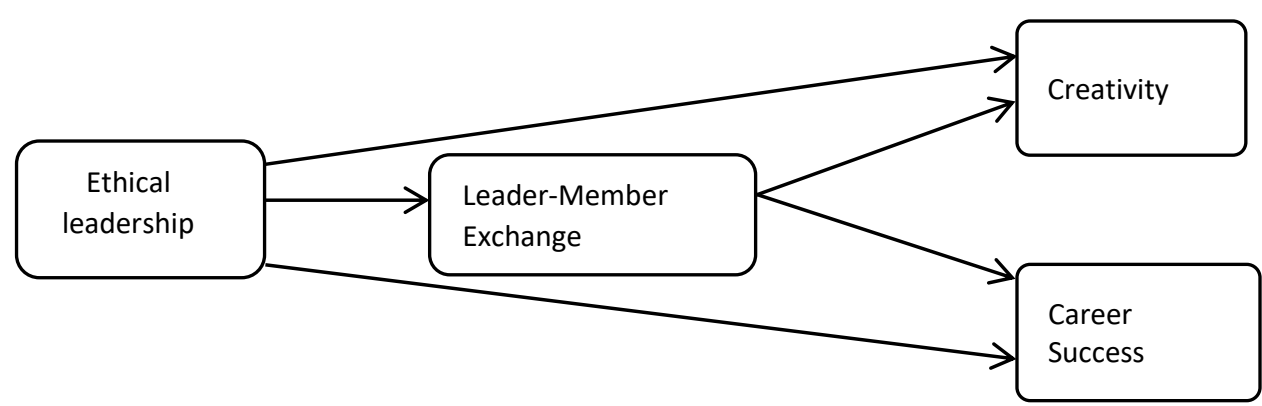

The hypotheses formulated are as follows:

$H_{1}$ : Ethical leadership perception of the member has a positive effect on member's leader-member exchange perception.

$\mathrm{H}_{2}$ : Member's leader-member exchange perception has a positive impact on his/her creativity.

$H_{3}:$ Member's leader-member exchange perception has a positive impact on his/her career success.

$\mathrm{H}_{4}$ : Ethical leadership perception of the member has a positive effect on member's creativity.

$H_{5}$ : Ethical leadership perception of the member has a positive effect on member's career success.

\subsection{Measures}

The survey was carried out on a sample consisted of employees of a Teknokent and 2 leading hotels in one of the provinces of Turkey. Simple random sampling technique was applied. Out of 68 firms employing a total of 122 people in the Teknokent 59 firms (90 employees in total) agreed to participate in the survey. The 2 hotels employ a total of 155 employees and 122 participated in the survey. Thus, the sample size is big enough to represent the population of the study.

Question form was used to collect data from the respondents in the sample and data were obtained by the researchers through face to face interviews. The question form consisted of measures used in past studies by many researchers and these measures were proven to have high reliability and validity. Member's leader-member exchange was measured with one-dimensional 7-item scale developed by Scandura and Graen (1984). Member's ethical leadership perception is measured with Brown, Trevino and Harrison's (2005) 10-item scale. Individual creativity perception was measured with 11 item scale developed by Munoz-Doyague et al. (2008). Career success was measured with 5 items by Greenhause et al. (1990). All scales are 5-point Likert type scales (1-certainly do not agree......5- certainly do agree).

\section{FINDINGS}

\subsection{Measure Assessments}

The descriptive statistics for demographic variables of the sample are given in Table 1: 
Table 1: Descriptive Statistics for Demographic Variables

\begin{tabular}{|c|c|c|c|c|c|c|c|}
\hline \multicolumn{2}{|c|}{ Characteristic } & \multirow{2}{*}{$\begin{array}{l}\mathbf{f} \\
36\end{array}$} & \multirow{2}{*}{$\begin{array}{l}\text { (\%) } \\
17.1 \\
\end{array}$} & \multicolumn{2}{|l|}{ Characteristic } & \multirow{2}{*}{$\frac{\mathbf{f}}{91}$} & \multirow{2}{*}{$\begin{array}{l}\text { (\%) } \\
43.5 \\
\end{array}$} \\
\hline \multirow{5}{*}{ Age } & $18-24$ & & & \multirow{4}{*}{ Gender } & Female & & \\
\hline & $25-31$ & 99 & 47.1 & & Male & 118 & 56.5 \\
\hline & $32-38$ & 53 & 25.2 & & High school or below & 59 & 29.6 \\
\hline & $39-45$ & 20 & 9.5 & & 2 year college & 44 & 22.1 \\
\hline & 46 or above & 2 & 1 & \multirow[t]{2}{*}{ Education level } & Graduate & 75 & 37.7 \\
\hline & & & & & Postgraduate & 21 & 10.6 \\
\hline & & & & \multirow{5}{*}{ Tenure } & $<1$ year & 42 & 20.3 \\
\hline & & & & & $1-5$ years & 89 & 43.0 \\
\hline & & & & & $6-10$ years & 46 & 22.2 \\
\hline & & & & & $11-15$ years & 23 & 11.1 \\
\hline & & & & & Above 15 & 7 & 3.4 \\
\hline
\end{tabular}

As seen in Table 1, $56.5 \%$ of respondents are male, $47.1 \%$ are in the age group of $25-31$ years, $37.7 \%$ have graduate degree and $43.0 \%$ have been working for $1-5$ years.

After data collection, a two-step structural equation modelling (SEM) procedure proposed by Anderson and Gerbing (1988) was employed with LISREL 8.7 software. The first step of the procedure examines scale validity from the measurement model using confirmatory factor analysis (CFA), while the second step focuses on hypotheses testing using the structural model. The convergent and discriminant validities of the whole measurement model were also analysed. The results of confirmatory factor analyses for the structural modal are summarized in Table 2.

Table 2: Summary Results of Confirmatory Factor Analysis for the Measurement Modal

\begin{tabular}{|c|c|c|c|}
\hline Model Construct & Measurement Item & Standardized Estimates & t- value \\
\hline \multirow[t]{5}{*}{ Ethical Leadership } & EL1 & 0.47 & 11.68 \\
\hline & EL2 & 0.67 & 8.56 \\
\hline & EL5 & 0.33 & 13.90 \\
\hline & EL6 & 0.31 & 14.11 \\
\hline & EL10 & 0.61 & 9.64 \\
\hline \multirow[t]{5}{*}{ Leader-Member Exchange (LMX) } & LMX1 & 0.44 & 12.30 \\
\hline & LMX2 & 0.28 & 14.90 \\
\hline & LMX3 & 0.34 & 13.89 \\
\hline & LMX4 & 0.36 & 13.57 \\
\hline & LMX5 & 0.36 & 13.64 \\
\hline \multirow[t]{5}{*}{ Creativity } & CRE1 & 0.53 & 10.68 \\
\hline & CRE3 & 0.57 & 10.12 \\
\hline & CRE6 & 0.34 & 13.62 \\
\hline & CRE7 & 0.36 & 13.21 \\
\hline & CRE9 & 0.43 & 12.24 \\
\hline \multirow[t]{4}{*}{ Career Success } & CARS1 & 0.23 & 15.74 \\
\hline & CARS2 & 0.18 & 16.42 \\
\hline & CARS3 & 0.42 & 12.61 \\
\hline & CARS5 & 0.44 & 12.38 \\
\hline
\end{tabular}

$\chi 2: 232.88 \quad \mathrm{df}: 146 \quad p$-value: 0.00001

NFI: $0.90 \quad \mathrm{NNFI}: 0.95 \quad \mathrm{CFI}: 0.96$

GFI: $0.90 \quad$ AGFI: $0.86 \quad$ RMSEA: 0.053

Comparing the fit indexes in Table 2 with the acceptable fit values in Table 3 below, it was observed that the structural modal exhibited good structural fit. 
Table 3: Acceptable and Good Fit Values

\begin{tabular}{|l|l|l|}
\hline Fit Index & Acceptable Value & Good Fit Value \\
\hline$\chi 2$ & - & - \\
\hline d.f & - & - \\
\hline$\chi 2 /$ d.f. & $2<\chi 2 / \mathrm{df} \leq 5$ & $0 \leq \chi 2 / \mathrm{df} \leq 2$ \\
\hline GFI & $0,85 \leq \mathrm{GFI} \leq 0,89$ & $0,90 \leq$ \\
\hline AGFI & $0,85 \leq \mathrm{AGFI} \leq 0,89$ & $0,90 \leq$ \\
\hline RMSEA & $0,06 \leq \mathrm{RMSEA} \leq 0,08$ & $\leq 0,05$ \\
\hline CFI & $0,95 \leq \mathrm{CFI} \leq 0,96$ & $0,97 \leq$ \\
\hline NNFI & $0,95 \leq \mathrm{NNFI}$ & \\
\hline NFI & $0,90 \leq \mathrm{NFI} \leq 0,94$ & $0,95 \leq$ \\
\hline
\end{tabular}

Source: Meydan and Şeşen, 2011.

Reliability and convergent validity indicators are presented in Table 4 below:

Table 4: Reliability and Convergent Validity Indicators

\begin{tabular}{|c|c|c|c|c|c|}
\hline Constructs & $\begin{array}{l}\text { Indicators/ } \\
\text { Items }\end{array}$ & $\begin{array}{l}\text { Factor } \\
\text { loading }\end{array}$ & $\begin{array}{l}\text { Composite } \\
\text { Reliability }\end{array}$ & AVE & $\begin{array}{l}\text { Cronbach's } \\
\text { alpha }\end{array}$ \\
\hline \multirow[t]{5}{*}{$\begin{array}{l}\text { Leader-member } \\
\text { Exchange }\end{array}$} & LMX1 & 0.75 & 0.900 & 0.644 & 0.901 \\
\hline & LMX2 & 0.85 & & & \\
\hline & LMX3 & 0.81 & & & \\
\hline & LMX4 & 0.80 & & & \\
\hline & LMX5 & 0.80 & & & \\
\hline \multirow[t]{5}{*}{ Ethical Leadership } & EL1 & 0.73 & 0.843 & 0.523 & 0.838 \\
\hline & EL2 & 0.57 & & & \\
\hline & EL5 & 0.82 & & & \\
\hline & EL6 & 0.83 & & & \\
\hline & EL10 & 0.63 & & & \\
\hline \multirow[t]{5}{*}{ Creativity } & CRE1 & 0.68 & 0.861 & 0.554 & 0.864 \\
\hline & CRE3 & 0.66 & & & \\
\hline & CRE6 & 0.81 & & & \\
\hline & CRE7 & 0.80 & & & \\
\hline & CRE9 & 0.76 & & & \\
\hline \multirow[t]{4}{*}{ Career Success } & CARS1 & 0.88 & 0.895 & 0.681 & 0.893 \\
\hline & CARS2 & 0.90 & & & \\
\hline & CARS3 & 0.76 & & & \\
\hline & CARS5 & 0.75 & & & \\
\hline
\end{tabular}

As seen in Table 4, the internal reliability values of the scales are high since Cronbach's alphas are higher than 0.70 for all constructs (Hair et al, 1998). For convergent validity, factor loadings should be significant and exceed 0.50 (Straub, 1989), composite reliabilities should exceed 0.60 (Bagozzi and $\mathrm{Yi}, 1988$ ) and the average variance extracted (AVE) should be more 
than 0.50 for all constructs (Fornell and Larcker, 1981). In this model, all factor loadings and composite reliabilities are within acceptable ranges and significant at the 0.01 level.

To assess discriminant validity, Fornell and Larcker's approach was utilized (Fornell and Larcker, 1981). In this approach, the square root of AVE for each construct should be higher than the correlation involving the constructs. Table 5 shows the bivariate correlation coefficients between constructs.

\section{Table 5: Bivariate Correlation Coefficients}

\begin{tabular}{|l|l|l|l|l|}
\hline & 1 & 2 & 3 & 4 \\
\hline 1. Ethical Leadership & 1 & & & \\
\hline 2. Leader-Member Exchange & 0.647 & 1 & & \\
\hline 3. Career Success & 0.295 & 0.181 & 1 & \\
\hline 4. Creativity & 0.337 & 0.388 & 0.350 & 1 \\
\hline
\end{tabular}

Comparing the $\mathrm{r} 2$ values in Table 5 with AVE values in Table 4 shows that the measurement model has satisfactory discriminant validity since the square root of AVE for each construct is higher than the correlation involving the constructs.

Since 2 paths in the research model didn't prove to be significant, they were excluded from further analysis. Table 6 shows the overall fit indices of the ultimate research model. As shown in Table 6, fit indices met satisfactory levels and the measurement model fits the data well.

Table 6: Overall fit indices of the ultimate path model

\begin{tabular}{|l|l|}
\hline Fit Index & Scores \\
\hline $\mathbf{\chi 2}$ & 250.99 \\
\hline $\mathbf{d f}$ & 149 \\
\hline $\mathbf{\chi 2} / \mathbf{d f}$ & 1.68 \\
\hline $\mathbf{p}$ & 0.00 \\
\hline $\mathbf{G F I}$ & 0.89 \\
\hline $\mathbf{A G F I}$ & 0.86 \\
\hline $\mathbf{R M S E A}$ & 0,057 \\
\hline $\mathbf{C F I}$ & 0.95 \\
\hline $\mathbf{N N F I}$ & 0.94 \\
\hline $\mathbf{N F I}$ & 0.89 \\
\hline
\end{tabular}

\subsection{Hypothesis Testing}

In Table 7, hypothesis testing results are summarized. $\mathrm{H} 3$ and $\mathrm{H} 4$ were not supported while $\mathrm{H} 1, \mathrm{H} 2$ and $\mathrm{H} 5$ were supported.

\section{Table 7: Hypothesis Testing Results}

\begin{tabular}{|l|l|l|l|l|}
\hline Hypothesis & Hypothesized path & Standardized coefficient & t value & Result \\
\hline H1 & EL-LMX & 0.73 & 9.12 & Supported \\
\hline H2 & LMX-CRE & 0.43 & 5.21 & Supported \\
\hline H3 & LMX-CARS & - & - & Not Supported \\
\hline H4 & EL-CRE & - & - & Not Supported \\
\hline H5 & EL-CARS & 0.33 & 4.38 & Supported \\
\hline * significant at the $p<0.05$ level & & & \\
\hline
\end{tabular}

\section{DISCUSSION AND CONCLUSION}

This study addresses the impact of ethical leadership on two important outcomes in the workplace, namely creativity and career success. The potential indirect impacts of ethical leadership on these outcomes via leader-member exchange were investigated as well as the direct effects. Although in organizational contexts creativity at the individual level has recently 
been studied through many aspects, its connection with ethical leadership has yet to be examined in detail. Besides, career success which has the potential to explain employee's attitudes towards work and behaviour in organizations is a relatively new concept in organizational behaviour and human resources literature needs further research.

The results of the survey in this study showed that ethical leadership has an indirect effect on creativity through leadermember exchange. In other words, as the employee's ethical leadership perception rises, their leader-member exchange perception rises as well. Thus, working with an ethical leader brings close interaction between employee and the leader, fosters employee's loyalty to the leader and commitment to the organizational tasks beyond formal requirements. In turn, high leader-member exchange leads to an increase in employee's creativity. This increase in employee creativity could be attributed to the positive psychological context established as a result of high quality interaction between these parties. Since creativity requires self-confidence, motivation, autonomy and the ability to think outside the box, the supportive communication style and manners of the leader would endorse these features and establish a work environment that could promote employee creativity.

Ethical leadership was found to have only a direct positive impact on career success. It was realised that leader-member exchange didn't have a statistically significant effect on career success contrary to the expectations of the researchers of this study. This finding implies that ethical leadership is a strong variable which has the ability to increase career success perception of the employee independent of them being in the in-group or out-group. So, if employees believe that their leader adopts ethical beliefs and performs ethically, they would be satisfied with their improvement in achieving career goals regarding promotion, salary and work success regardless of the quality of their relationship with the leader.

This study has some implications for managers and practitioners. First, managers should attempt to improve their ethical leadership skills and foster an ethical work climate. Leaders should convey moral standards to employees, establish the mechanisms to follow up the behaviours of the employees on the basis of these standards and reward members who internalize them. By this way they could improve the quality of the relationship with followers. In turn, the rise in the quality of the relationship with followers would bring creativity. In order to improve the subjective career success perception of the employees, managers should exhibit ethical leadership because leader's ethical behaviours affect all employees' career success perceptions positively regardless of their personal intimacy with the leader. Ethical leadership might bring a sense of meaning to the work and the employees would find their jobs and career more satisfactory.

Like all studies, this study has some limitations. First, the study was carried out in business organizations and two hotels in a providence of Turkey, so the results are only generalizable for the relevant population. Second, data is cross sectional in nature and in order to infer causal relationships, longitudinal studies should be conducted. In future studies, collecting data from leader-member dyads would be beneficial in terms of getting a broader and more objective picture about the relationship between leader and member and the impact of the quality of this relationship on various work outcomes. For instance, employee creativity could be measured with the leader's evaluation and more objective findings could be reached. Also, future studies should include other work outcomes and investigate the impact of ethical leadership on these outcomes.

\section{REFERENCES}

Anderson, J. C., Gerbing, D. W. (1988). Structural equation modeling in practice: a review and recommended two-step approach. Psychological Bulletin, 103(3), 411-423.

Atılmış, T. (2016). Effect of locus of control and leader member exchange on job satisfaction in business (Unpublished Master Thesis). Balıkesir: Balıkesir University.

Atwater, L., Carmeli, A. (2009). Leader-member exchange, feelings of energy, and involvement in creative work. The Leadership Quarterly, 20(3), 264-275.

Avey, J. B., Wernsing, T. S., Palanski, M. E. (2012). Exploring the process of ethical leadership: the mediating role of employee voice and psychological ownership. Journal of Business Ethics, 107(1), 21-34.

Bagozzi, R. P., Yi, Y. (1988). On the evaluation of structural equation model. Journal of Academy of Marketing Science, 16(1), 74-94.

Bas, T., Keskin, N., Mert, İ. S. (2010). Leader member exchange (LMX) model and validity and reliability of its instrument in Turkish. Ege Academic Review, 10(3), 1013-1039.

Blau, P. (1964). Power and exchange in social life. New York: J Wiley \& Sons.

Bolat, O. I. (2011). The relationship between leader member exchange and burnout. İş-Güç Industrial Relations and Human Resources Journal, 13(2), pp.63-80.

Brown, M. E. Trevıno, L. K., Harrison, A. D. (2005). Ethical leadership: a social learning perspective for construct development and testing. Organizational Behavior and Human Decision Processes, 97(2), 117-134. 
Budak, G., Gürbüz, S. (2016). Çok boyutlu öznel kariyer başarisi: bir ölçek uyarlama çalişması. 4. Örgütsel Davranış Kongresi, 4-5 November, Çukurova University, 460-470.

Can, H. (2005). Organizasyon ve yönetim (7. press). Ankara: Siyasal Kitabevi.

Carnevale, J. B., Huang, L., Crede, M., Harms, P., Uhl-Bien, M. (2017). Leading to stimulate employees ideas: a quantitative review of leadermember exchange, employee voice, creativity and innovative behavior. Applied Psychology: An International Review, 66(4), 517-552.

Cemaloğlu, N., Kılınç, A. Ç. (2012). The relationship between school principals' ethical leadership behaviors and teachers' perceived organizational trust and mobbing. Education and Science, 37(165), 137-151.

Chen, Z., Lam, W., Zhong, J. A. (2007). Leader-member exchange and member performance: a new look at individual-level negative feedback-seeking behavior and team-level empowerment climate. Journal of Applied Psychology, 92(1), 202-212.

Chen, A., Hou, Y. (2016). The effects of ethical leadership, voice behavior and climates for innovation on creativity: a moderated mediation examination. The Leadership Quarterly, 27(1), 1-13.

Chughtai, A. A. (2016). Can ethical leaders enhance their followers' creativity?. Leadership, 12(2), 230-249.

Cindiloğlu, M., Polatcı, S., Özçalık, F., Gültekin, Z. (2017). The effects of workplace loneliness on job and life satisfaction: the mediating role of leader-member exchange. Ege Academic Review, 17(2), 191-200.

Daft, R. L., Steers, R. M. (1986). Organizations: a micro/macro approach. Scott Foresman \& Co.

Dansereau, F., Cashman, J., Graen, G. (1973). Instrumentality theory and equity theory as complementary approaches in predicting the relationship of leadership and turnover among managers. Organizational Behavior and Human Performance, 10(2), 184-200.

Deluga, R. J. (1994). Supervisor trust building, leader-member exchange and organizational citizenship behaviour. Journal of Occupational and Organizational Psychology, 67(4),.315-326

Deluga, R. J., Perry, J. T. (1994). The role of subordinate performance and ingratiation in leader-member exchanges. Group \& Organization Management, 19(1), 67-86

Dienesch, R. M., Liden, R. C. (1986). Leader-member exchange model of leadership: a critique and further development. Academy of Management Review, 11(3), 618-634.

Erdogan, B., Liden, R. C., Kraimer, M. L. (2006). Justice and leader-member exchange: the moderating role of organizational culture. Academy of Management Journal, 49(2), 395-406.

Fornell, C., Larcker, D. F. (1981). Evaluating structural equation models with unobservable variables and measurement error. Journal of Marketing Research, 18(1), 39-50.

Greenhause, J. H., Parasuraman, S., Wormley, W. M. (1990). Effects of race on organizational experiences, job performance evaluations and career outcomes. Academy of Management Journal, 33(1), 64-86.

Gerstner, C. R., Day, D. V. (1997). Meta-analytic review of leader-member exchange theory: correlates and construct issues. Journal of Applied Psychology, 82(6), 827-844

Gu, Q., Tang, T., Jiang, W. (2015). Does moral leadership enhance employee creativity? Employee identification with leader and leadermember exchange (LMX) in the Chinese context. Journal of Business Ethics, 126(3), 513-529.

Gürbüz, R. (2012). The relationship between organizational commitment perceived organizational support and organizational trust (Unpublished Master Thesis). Erzurum: Atatürk University.

Hair, J. F., Anderson, R. E., Tatham, R. L., Black, W. C. (1998). Multivariate data analysis. New Jersey: Prentice Hall.

Hall, D. T. (2002). Careers in and out of Organizations. Sage Publishing.

Hall, D. T., Chandler, D. E. (2005). Psychological success: when the career is a calling. Journal of Organizational Behavior, 26(2), 155-176.

Harris, K. J., Kacmar, K. M., Carlson, D. S. (2006). An examination of temporal variables and relationship quality on promotability ratings. Group \& Organizational Management, 31(6), 677-700.

Javed, B., Khan, A. A., Bashir, S., Arjoon, S. (2017). Impact of ethical leadership on creativity: the role of psychological empowerment. Current Issues in Tourism, 20(8), pp.839-851.

Javed, B., Rawwas, M., Khandai, S., Shadid, K., Tayyeb, H. (2018). Ethical leadership, trust in leader and creativity: the mediated mechanism and interacting effect. Journal of Management and Organization, 1-18.

Jex, S. M., Britt, W. T. (2008). Organizational psychology: a scientist-practitioner approach (2. press). Canada: John Wiley ve Sons.

Kanbur, E., Özyer, K. (2016). The effect of individual creativity level of employees on their intrapreneurship performance. Yönetim ve Ekonomi Araştırmaları Dergisi, 14(2), 264-275.

Kaşlı, M., Seymen, O. A. (2015). Personality traits, leader-member exchange and exhaustion relation. Dumlupınar Üniversitesi Sosyal Bilimler Dergisi, 27, 109-122. 
Katı, Y. (2016). The Relationship between political skills of emloyees and career success: the mediating effect of leader member exchange (Unpublished Master Thesis). Balıkesir: Balıkesir University.

Katz, D., Kahn, R. L. (1978). The social psychology of organizations (2. Ed.). New York: John Wiley and Sons.

Kesen, M. (2016). Examining the work alienation of academic staff from the perspective of ethical leadership and demographic variables: an empirical study. The Journal of Academic Social Science, 4(22), 118-134.

Liden, R. C., Erdoğan, B., Wayne, S. J., Sparrowe, R. T. (2006). Leader-Member exchange, differentiation, and task interdependence: implications for individual and group performance. Journal of Organizational Behavior, 27(6), 723-746.

Liden, R. C., Maslyn, J. M. (1998). Multidimensionality of leader-member exchange:an empirical assessment through scale development. Journal of Management, 24(1), 43-72.

Ma, Y., Cheng, W., Ribbens, B., Zhou, J. (2013). Linking ethical leadership to employee creativity: knowledge sharing and self-efficacy as mediators. Social Behavior and Personality: An International Journal, 41, 1409-1420.

Mehmood, S. (2016). Impact of ethical leadership on employee creativity: mediating role of trust and moderating role of creative self efficacy. Jinnah Business Review, 4(2), 65-74.

Meydan, C. H., Şeşen, H. (2011). Yapısal eşitlik modellemesi: AMOS uygulamaları. Ankara: Detay Yayıncılık.

Munoz-Doyague, M. F., Gonzalez-Alvarez, N., Neito, M. (2008). An examination of individual factors and employees' creativity: the case of Spain. Creativity Research Journal, 20(1), 21-33.

Neubert, M. J., Carlson, D. S., Kacmar, K. M., Roberts, J. A., Chonko, L. B. (2009). The virtuous influence of ethical leadership behavior: evidence from the field. Journal of Business Ethics, 90(2), 157-170.

Palanski, M., Vogelgesang, G. R. (2011). Virtuous creativity: the effects of leader behavioural integrity on follower creative thinking and risk taking. Canadian Journal of Administrative Sciences, 28(3), 259-269.

Peng, J., Chen, Y., Xia, Y., Ran, Y. (2017). Workplace loneliness, leader-member exchange and creativity: the cross-level moderating role of leader compassion. Personality and Individual Differences, 104, 510-515.

Phillips, A. S., Bedeian A. G. (1994). Leader-follower exchange quality: the role of personal and interpersonal attributes. Academy of Management Journal, 37(4), 990-1001.

Qu, R., Shi, K., Gao, L. (2012). When leader-member exchange promotes employee creativity. Proceedings of the International Conference on Information Management, Innovation Management and Industrial Engineering, ICIII. International Conference, $194-197$.

Qu, R., Janssen, O., Shi, K. (2017). Leader-member exchange and follower creativity: the moderating roles of leader and follower expectations for creativity. International Journal of Human Resource Management, 28(4), 603-626.

Scandura, T. A., Graen, G. (1984). Moderating effects of initial leader-member exchange status on the effects of a leadership intervention. Journal of Applied Psychology, 69(3), 428-436.

Schriesheim, C. A., Scandura, T. A., Eisenbach, R. J., Neider, L. L. (1992). Validation of a new leader-member exchange scale (LMX-6) using hierarchically-nested maximum likelihood confirmatory factor analysis. Educational and Psychological Measurement, 52(4), 983-992.

Seibert, S. E., Kraimer, M. L. (2001). The five-factor model of personality and career success. Journal of Vocational Behavior, 58(1), 1-21.

Shalley, C. E., Gilson, L. L., Blum, T. C. (2000). Matching creativity requirements and the work environment: effects on satisfaction and intentions to leave. Academy of Management Journal, 43(2), 215-223.

Straub, D. W. (1989). Validating instruments in MIS research. MIS Quarterly, 13(2), 147-69.

Yıldırım, E. (2007). Creativity in the age of information and importance of managing creativity. Karamanoğlu Mehmetbey Üniversitesi Sosyal ve Ekonomik Araştırmalar Dergisi, 12(9), 109-120.

Yıldırım, A. (2010). An application on the relationship between ethical leadership and organizational justice (Unpublished Master Thesis). Karaman:Karamanoğlu Mehmet Bey University.

Yılmaz D. (2007). The effect of social culture on institutional culture and human resources applications (UnPublished Master Thesis). İstanbul:Marmara University.

Wayne, S. J., Green, S. A. (1993). The effects of leader-member exchange on employee citizenship and impression management behavior. Human Relations, 46(12), 1431-1440.

Woodman, R. W., Sawyer, J. E., Griffin, R. W. (1993). Toward a theory of organizational creativity. Academy of Management Review, 18(2), 293-321.

Zahra, T. T., Waheed, A. (2017). Influence of ethical leadership on innovative work behavior: examination of individual-level psychological mediators. Pakistan Journal of Commerce and Social Sciences, 11(2), 448-470. 